\title{
DÜBLIN
}

Technological University Dublin

ARROW@TU Dublin

\section{Legal Frameworks for Media and Information Literacy}

\author{
María-del-Mar Grandío \\ Sirin Dilli \\ Brian O'Neill \\ Technological University Dublin, brian.oneill@tudublin.ie
}

Follow this and additional works at: https://arrow.tudublin.ie/cserbk

Part of the Social and Behavioral Sciences Commons

\section{Recommended Citation}

Grandío, M.-M., Dilli, S., \& O’Neill, B. (2017). 3 Legal frameworks for Media and Information Literacy. In Divina Frau-Meigs, Julieta Flores Michel, \& Irma Velez (Eds.), Public policies in media and information literacy in Europe : cross-country comparisons (pp. 116-129). Abingdon, Oxon: Taylor and Francis. https://doi.org/10.4324/9781315628851

This Book Chapter is brought to you for free and open access by the Centre for Social and Educational Research at ARROW@TU Dublin. It has been accepted for inclusion in Books/Book chapters by an authorized administrator of ARROW@TU Dublin. For more information, please contact arrow.admin@tudublin.ie, aisling.coyne@tudublin.ie, gerard.connolly@tudublin.ie.

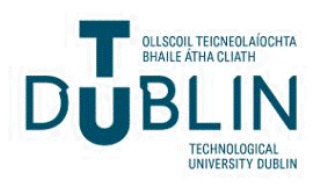


Across Europe and beyond, efforts are growing to promote the wider use of digital media by all citizens - adults and young people alike. As such, an increasingly prominent role is being given to the notion that media literacy is a precondition for full and effective participation in contemporary societies. In such a context, interests of policymakers focusing on promoting the benefits of a wider societal digital participation intersect with the traditional function of media literacy to promote enhanced skills and competencies of citizens to access, create and understand media content. Accordingly, a concern with media literacy has moved from being a matter solely of interest to media educationalists to a question of public policy with a variety of stakeholders and actors involved in the process. As a result, Media Information Literacy (MIL), particularly in a digital context, is now a recurring theme within policy platforms dedicated to culture, education and greater social cohesion.

Our focus in this chapter is on the legal expression of media literacy with particular reference to the ethical and social challenges faced by citizens in the media and information society. Drawing on the relevant literature in the field, our objective here is to develop greater theoretical specificity through the analysis of concepts and relationships mapped against the actual data from the Translit project. Close reading of country reports produced in the course of the Translit enables us to generate questions, to extend the literature on legal frameworks for MIL and policy and to assess how it applies to varied situations across Europe.

In this chapter, we summarise and synthesize the landscape of legal frameworks for MIL. Following a review of all 28 European country reports from the Translit project, the aim is to better understand the extent to which different cultures and institutions within Europe participate within the MIL process. Our premise is that the policy debate around media and information literacy has been transformed since the 1990s. Tectonic shifts in the technical, economic, and policy domains have brought us to a new media landscape.

If in an educational context, media literacy built up a well-documented field of critical enquiry regarding media, its content and consumption, the policy dimensions of media 
literacy have received much less attention. The notion that various public institutions government ministries, media regulatory authorities, broadcasting organisation - are viewed as having obligations towards media literacy and for which they are accountable is of relatively recent origin. Neither has its presence within public policy been without controversy. In this new media ecosystem where almost endless information is pervasive in everyday life, how can people become media literate? Can we and/or should we train people to become more critical? How should we give the capacity and the ability to check what is right or wrong information on today's media landscape? Should we refer here about information literacy, media literacy and/or technology literacy? And most important, how can legal frameworks improve media literacy in a European context?

The development of media literacy as represented through legal frameworks drawing on the 28 national reports produced for the Translit project led us to suggest two particular avenues/entries for MIL to show up in a policy context: education and human rights. Our analysis distinguishes between those countries in which a legal expression of media literacy as a public policy objective is: a) still at the initial stages, b) at an advanced stage of development or c) fully present. The chapter then proceeds to contrast countries with no legal approach towards the framing of media literacy (Bosnia-Herzegovina, Serbia, Latvia and Romania) with those with specific strategies to promote media literacy policy (Denmark and Finland). Finally, the chapter assesses the most important issues, challenges and debates facing the further implementation of legal frameworks for media literacy at the local/national/translational level, with particular reference to the impact of digital technologies on education and media literacy policies.

\section{Media Information Literacy in a cross-national policy context}

The policy orientation of media literacy is implicit in many of the practices of media education with a strong public dimension and democratic orientation a notable feature of its underpinning. Len Masterman stated many years ago, that: "At stake is the empowerment of majorities and the strengthening of society's democratic structures" (Masterman 1985). Divina Frau-Meigs recently raised the issue for the European context (2011: 367). "Policy makers" she argues, "need to overcome the perceived risks that media education might threaten governmental power, national sovereignty and even the cultural identity of a country. In fact it can lead to everybody's empowerment if set within a framework of good 
governance where the benefits of the new cognitive ways of learning are shared, peoplecentred and not simply machine-induced".

Media education, advocates argue, is inextricably bound up with human rights and freedom of information and expression. The outcome of media education is the ability to make "one's own judgment on the basis of the available information" (Krucsay 2006). In fostering a sense of critical autonomy, the media literate person is empowered through a greater understanding of how the media mediate reality, rather than simply reflect it, and accordingly is better prepared to participate in society on more equal terms. Others have called for the linking of media studies in schools with civic and social studies arguing that "in a representative democracy, people must be educated in all forms of contemporary mediated expression and well beyond the print media" (Frau-Meigs 2011, p. 367). Up to relatively recently, however, the objective of media literacy education, whether related to language, arts or civics, has been education of young people in full-time educational settings through curricula designed to foster greater critical awareness at an individual level.

UNESCO has argued that optimal utilisation of the public space fundamentally relies on media literacy skills, and realising the full range of possibilities that media literacy offers. In a rapidly developing information and communications environment, therefore, regulatory bodies need to ensure a commitment to public access and utilise new and emerging platforms to enable participation and interaction, coverage of public events and major governance institutions and support for minorities and other interests who may require special measures to achieve full citizen-participation and information sharing.

A further impetus for greater recognition of media literacy within public policy discourse and within a distinct legal framework has been derived from the growing consensus that media and information literacy are best conceived through the lens of human rights (Frau-Meigs 2008) or more specifically in communication rights, in turn derived from basic human rights, as guaranteed through such international declarations as the Universal Declaration of Human Rights (1948), the Convention for the Protection of Human Rights and Fundamental Freedoms (1950) and the UN Convention on the Rights of the Child (1990).

The public dimension of media literacy owes much, therefore, to the interventions of inter-governmental organisations such as UNESCO and the Council of Europe who 
successively initiated the concept of media education in the $1970 \mathrm{~s}$ and sought its incorporation into the education systems of all developed countries (Zgrabljic-Rotar 2006, p. 10). More recently, the Council of Europe's support for the public service value of the Internet, for instance, focuses attention on strategies for realisation of the full democratic potential of the information society and the development of appropriate public spaces and information as a public good (Council of Europe, 2006a). In this regard, its Recommendation on Empowering Children in the New Information and Communications Environment, adopted in 2006, advocated "a coherent information literacy and training strategy which is conducive to empowering children and their educators in order for them to make the best possible use of information and communication services and technologies" (Council of Europe, 2006b, p. 1). Member states accordingly are required to ensure that young people are familiarised with, and skilled in, the new information and communications environment, have the necessary skills to create, produce and distribute content and communications, and that such skills should better enable them to deal with content that may be harmful in nature. A supporting Internet Literacy Handbook, published by the Council's Media Division, acts as a guide for parents, teachers and young people (Council of Europe, 2006c).

\section{Media Literacy in the regulatory domain}

Increasingly, it is in the regulatory realm that responsibility rests for the creation and maintenance of a democratic public sphere. This realm is here national and EU mandated. Obviously, media and information literacy is a concept that has in the last decade acquired an important place within legal frameworks, particularly in member states and to some extent, candidate states of the European Union.

Building on its long history within pedagogical and media studies discourse, its presence within a more administrative policy context has been a matter of debate. Media regulators in particular were, and still are deemed to have a central role in the management of those public spaces where an information commons is created and maintained through a diverse and pluralist broadcasting landscape with public service broadcasting, in particular, a key instrument in promoting citizens' democratic participation and access to public life (Banerjee and Seneviratne 2005, p. 12). Against a background of increasing marketisation and erosion of the public sphere through fragmentation, institutions such as public service broadcasting and the underpinning regulatory frameworks now play a central role in defining 
that public space in which rights for information, communication and expression are exercised and enjoyed.

Within the European Union, there are now a number of important legislative and regulatory initiatives governing media literacy across different European institutions as evidenced by the resolution of the European Parliament of 6 November 2008 wishes "Media literacy to be made the ninth key competence in the European reference framework for lifelong learning" (Council of the European Union, 2006). A wider inclusion during the revision of the Directive On Audiovisual Media Services, in 2014, is also anticipated.

Yet, the lack of reference to information literacy in EU documents is notable. What does media literacy mean in the digital age? In terms of literacy, in the digital age, access to knowledge seems evident in schools. But what does having access to read Google results mean? Does every person have access to it? What gives priority in certain legal frameworks to MIL literacy or to digital literacy?

The European Commission's Communication (European Commission, 2003) on the future of European regulatory audiovisual policy, emphasised the role of regulatory policy in safeguarding public interests, such as cultural diversity, the right to information, media pluralism, the protection of minors, consumer protection and the need to enhance public awareness and media literacy.

The pre-eminent instrument of European media policy is the Audiovisual Media Services Without Frontiers Directive (AVMSD), (European Union, 2010) offering "a comprehensive strategy designed to encourage the production of European content, the development of the digital economy and the uptake of information and communication technologies (ICT), against the background of the convergence of information society services and media services, networks and devices" (2010, p. 14). Of central importance is the inclusion of media literacy within the terms of AVMSD, in which all member states from 2011 have been required to report on levels in their respective countries. Media literacy, as defined in the Directive, refers to the 'skills, knowledge and understanding that allow consumers to use media effectively and safely' (2010, p. 47). Opportunities for the development of media literacy are also specifically referenced in relation to measures for the protection of minors and human dignity and for exercise of the right to reply. 
An important building block of European policy on media literacy was added in 2007 with the publication of a Communication on Media Literacy by the European Commission ( $A$ European approach to media literacy in the digital environment). Building on the work of the Commission's Media Literacy Expert Group established in 2006, the conclusions of a public consultation in the field of media literacy, and new research on media literacy (Universitat Autònoma de Barcelona 2007), the Communication provided new scope for the development of policy and legal frameworks in the areas of commercial communication, audiovisual works and online communication. Expanding on the definition in AVMSD, it presents media literacy as: "the ability to access the media, to understand and to critically evaluate different aspects of the media and media contents and to create communications in a variety of contexts". Levels of media literacy are described as including:

a. Feeling comfortable with all existing media from newspapers to virtual communities; Actively using media, through, inter alia, interactive television, use of Internet search engines or participation in virtual communities, and better exploiting the potential of media for entertainment, access to culture, intercultural dialogue, learning and daily-life applications (for instance, through libraries, podcasts);

b. Having a critical approach to media as regards both quality and accuracy of content (for example, being able to assess information, dealing with advertising on various media, using search engines intelligently);

c. Using media creatively, as the evolution of media technologies and the increasing presence of the Internet as a distribution channel allow an ever growing number of Europeans to create and disseminate images, information and content;

d. Understanding the economy of media and the difference between pluralism and media ownership;

e. Being aware of copyright issues which are essential for a "culture of legality", especially for the younger generation in its double capacity of consumers and producers of content.” (European Commission, 2007, p. 4).

As a result of such initiatives and policy prompts, media literacy promotion either currently is, or is in the process of becoming, a central feature for media regulators in many jurisdictions, in Europe and internationally. Legislation and models of regulation, including 
co- and self-regulation feature prominently in this regard. In the following, we discuss these features in the context of the findings from the Translit survey.

\section{Analysing Media Literacy and legal frameworks across Europe}

Within the Translit project, wide regional and cultural differences were found regarding legal frameworks among the countries analyzed. The distinct values associated with differing arrangements in individual member states emerge from negotiations between needs, interests, political systems and their institutions. At present, only a few states have put in place national media literacy related policies and elaborated the strategies that are needed to sustain their efforts. However, more and more countries are recognizing the importance of legal frameworks. In modelling three different types of legal frameworks, therefore, new local and regional variation emerges across the 28 European Union countries that are implementing media literacy related activities in varying degrees and reach.

Countries at the initial stage of implementation (Bosnia-Herzegovina, Serbia, Latvia, Romania)

Those countries that are at the first stage of implementation of media literacy through legal frameworks are typically late joiners of the EU that have experienced post-communist democratisation of media freedoms which have had an important impact on developing legal frameworks on media literacy.

A common characteristic among these countries is the lack of legal definition of media literacy together with the lack of jurisdiction or institutions to promote media education. For instance, in Bosnia-Herzegovina there are no laws to regulate media education. As the national team of the project underlines, no jurisdiction is defined nor institutions to promote media education, coordination of activities regarding media education as well as reporting on the level of media literacy (Turcilo and Tajić, 2013). Given the status of Bosnia-Herzegovina within the EU accession process, there is either no obligation to report on current levels of media literacy to the European Commission or any other EU body. Similarly in Serbia, there is no single or widely accepted official definition of media education although media literacy is primarily associated with information literacy and critical thinking. As it is highlighted by its national team, MIL overlaps with other literacies, visual and film literacy being one of those (Matović, Milin, and Perković, 2013). Taking into 
account specific policies, Serbia does not have an explicit media education policy. However, the issue is recognized as important in various audio-visual and education documents implying a greater consciousness of the topic to promote media literacy in the future. As an example of this new sensibility, MIL is implicitly recognized as one of the competencies and an outcome of functional literacy in Education Development Strategy in the Republic of Serbia until 2020 (Government of the Republic of Serbia, 2012). This document was adopted by the Serbian Government in 2012 and determines guidelines for the development of education for the period 2012-2020. Media education and media literacy are implicitly recognized and assumed through fostering digital competences, social and civic competences, cultural awareness and expression and principles of active learning (Matović, Milin, and Perković, 2013). Latvia legislation is in a similar position in this regard and seeks to keep a balance between out-dated and old legal national acts (Law On the Press and Other Mass Media adopted in 1990) and more recent EU directives that notice the steps taken by this first group of countries in order to implement EU policy (Brikše, Freibergs, and Spurava, 2013).

The second relevant issue is this group of countries at the initial stage of implementation is their focus mainly on digital and information literacies when it is approached by legal documents. This is a feature this group of countries shares with other countries that are further advanced in their implementation of MIL. For instance, digital and information literacy has been mentioned as key competence for compulsory education in Romania ever since the 2003 Report on the Reform of Compulsory Education (Stanila and Fotiade, 2013). Like many of the countries in this first stage of implementation, media education in Romania is understood in its wider cultural and critical context has not so far been officially defined in national policy documents. In addition to the absence of media education policy, no legal public authority supervises MIL. At present, media education policy in Romania focuses on the integration of Information Tecnology (IT) education and elearning in formal.

Due probably to the lack of public policies supporting media literacy, the third characteristic of these countries is the emergence of the private and civic sector to encourage $M I L$, specially focused on promoting computer and IT literacy. Positive examples of private sector initiatives on media literacy were highlighted by the Serbian team including the project Partners in learning Microsoft BiH. In 2008 Microsoft BiH signed Memoranda of 
Understanding with the ministries of both entities aiming to increase IT literacy and usage of modern technologies in education within the global Microsoft initiative Partners in learning. This global initiative is aimed to improve the access to different technologies and their usage in the education process of the citizens. The goal of this programme is to help schools and educational institutions to introduce innovative approaches in pedagogy and to promote professional teachers' training and by computer aided learning, equip students for the challenges of the future (Matović, Milin, and Perković, 2013).

Countries at an advanced stage of implementation (UK, France, Germany, Ireland and Spain)

Countries that offer a more advanced stage of implementation of MIL within a legal framework include the United Kingdom, France, Germany, Ireland and Spain. These are all mainly European countries with established media and press systems that have sought to promote a greater understanding of communication and media literacy issues through recognition within a legal context.

Most countries at an advanced stage of implementation have a legal framework on media literacy, mostly coming from national laws on Communications or other reference texts that standardise some of the principal recommendations of the EU on the matter. For instance, the UK is a leader in this space, given that the first occasion that media literacy featured in law was in the Communications Act of 2003. As in the UK, legislation in Ireland in the form of the Broadcasting Act (2009) provides a role for media literacy within the public sphere (O’Neill, 2013). In France, media education has since 2000 benefited from a series of reference texts, integrating and standardizing some of the relevant recommendations of the EU and several symbolic declarations (Grünwald, Paris Agenda, European Charter for Media Literacy, etc.). In addition, a series of education reform acts have promoted its implementation in the school curriculum and maintained the production of educational documents (Frau-Meigs, Loicq and Boutin, 2013).

Secondly, common features of countries at a more advanced stage of implementation are the presence of national or regional bodies on media literacy to supervise media literacy issues. These include, for example: Office of Comunications (OFCOM) in the UK, "Centre de Liaison de l' Enseignement et des Médias d' Information" (CLEMI) in France and the 
Broadcasting Authority of Ireland (BAI). The UK 2003 Communications Act gave rise to a new media regulator in UK, OFCOM, with a clear responsibility and task of promoting media literacy. OFCOM gave media education a status and legitimation that it lacked before in UK and the rest of Europe (McDougall, Livingstone, Sefton-Green, and Fraser, 2013). In Ireland, the Broadcasting Authority of Ireland (BAI) is a single content regulator, with responsibility for oversight of public service broadcasters. As a regulator, it also has ancillary functions to encourage and foster research and to undertake measures and activities which are directed towards the promotion of media literacy (O’Neill, 2013).

There is also in Ireland a broadcasting funding scheme that may be used to support new television or radio programmes promoting media literacy. Also included in the legislation are other measures supporting public participation in the media. These include the establishment of Audience Councils by public service broadcasters to represent the views of listeners and viewers. The legislation also creates a right of reply mechanism whereby individuals who feel their reputations have been damaged may have this corrected in a further broadcast. The regulator also has the responsibility under the Audiovisual Media Services Directive, to report on levels of media literacy across Europe from 2011 (O’Neill, 2013). France is also a pioneer in the promotion of media education through an institutional agency devoted to MIL: CLEMI. This structure has responsibility for media education, as an independent entity, in close contact with academia and the local education authorities. The role of CLEMI is to centralize resources and training offered within schools and to disseminate it via a network of local coordinators, with partnerships with various public and private organizations (Frau-Meigs, Loicq and Boutin, 2013). In Germany, there is no central body that is in the position to decide on legal media related issues with national scope, as it also happen in Spain. The two most relevant bodies for the area of media education and literacy are the Interstate Broadcasting Treaty in Unified Germany and the Interstate Treaty on the Protection of Human Dignity and the Protection of Minors in Broadcasting and in Telemedia. In addition, the regional media authorities have built a national representation: "die medienanstalten" (the media authorities) set out to coordinate any issue that requires solutions at a national level. One of its remarkable bodies is the Commission for the Protection of Minors in the Media (Kammerl, and Hasebrink, 2013). 
A further characteristic of this group of countries marked within an advanced stage is the proliferation of organizations emanating from civil society provide MIL training in nonformal education, outside schools. For instance, in Ireland the community media movement has been an important actor in promoting media literacy and with the support of the media regulator has utilised the production funding scheme, Sound and Vision to enable producers to target media literacy education as a recognized topic of broadcast content (O’Neill, 2013). In France, APTE, Fréquence École, Centres d'Entrainement aux Méthodes d'Education Active (CEMÉA), La ligue, to name a few. CLEMI is connected to the Le réseau de creation et d'accompagnement pédagogiques (CANOPÉ) network (ex-SCEREN/CNDP), an administrative national public institution placed under the supervision of the Ministry of Education. CANOPÉ offers a large range of educational collections, including one collection for media literacy. The agreement with France Télévisions has established a partnership with Curiosphere (renamed FranceTV Education since 2012), an educational platform for parents and children that create games and multimedia resources available and free for the citizens (Frau-Meigs, Loicq and Boutin, 2013).

Although the success of the implementation of a legal framework and public regulators of MIL in these countries that it has been described above, there are problems of managing media policies within this context when different legal bodies are involved. For instance, as underlined by the British team, the UK experienced something of a collapse of MIL due to oversight by a government department outside of education and following policy changes regarding the role of the media regulator (McDougall, Livingstone, Sefton-Green, and Fraser, 2013). Other countries report similar challenges when there is no independent state agency to regulate media content with enforcement capacities. For instance, in Spain there is no agency at the state level with a mandate to regulate and monitor media content, especially regarding the protection of childhood. The experience of the Audiovisual Councils in Spain is so far reduced to some regions like Andalusia, Navarra and Catalonia. Even among existing ones, only the Audiovisual Council of Catalonia meets on a regular basis. Although their activities and research have been beneficial and there have been attempts to create an Audiovisual State Council, this project has fallen through due to partisan conflicts (Grandío, Vicente, García-Matilla, Gutiérrez-Martín, Marta-Lazo, 2013).

\section{Countries in which implementation is almost fully present}


None of the Translit Project reports represented the legal framework of their countries as fully present. This is primarily because many challenges still remain in the European context, even in those countries with a long historical background in MIL implementation. However, two countries may be cited as remarkable examples because they show a solid presence of MIL in legal documents or public institutions by comparison with the rest of Europe. Both Finland and Denmark stand out in this respect particularly in the link established between MIL and human rights and citizenship.

For these Nordic countries, media literacy is an important element for participation and inclusion in society. These are countries that aim to develop media education by fostering equality, diversity and quality on the basis of human rights. As such, MIL in these countries is an embedded cross-cutting theme seen in different policy areas, including cultural policy, youth policy, art and artist policy, general education policy including early childhood education and library policy. For instance, the Ministry of Justice in Finland addresses media education from the viewpoint of social inclusion as part of democratic education. In 2007 the Ministry of Education set up a committee to chart the state and development needs of media literacy in Finland. This committee worked for a proposal for an action programme to develop media skills and knowledge as a part of the promotion of civil and knowledge society which included ideas to modify policies concerning civil rights, core curricula and teacher training. It also remarkable to mention the latest strategy plan by Ministry of Education and Culture in Finland: Good Media Literacy National Policy Guidelines 20132016, published in the end of year 2013 (Ministry of Education and Culture, 2013). These policy guidelines for good media literacy are built on the principles set out in the UN Convention on the Rights of the Child to help achieve the goal in the Government Programme of assuring that every child and young-adult in Finland has the tools for participating and accessing information and communication (Kotilainen and Kupiainen, 2013). Denmark is another country where we can find media policies fully present in different levels including namely formal education (primary, lower-secondary, uppersecondary education) and semi-formal education with key players such as the Danish Film Institute, public libraries, and the Media Council for Children and Young People in Denmark "Medierådet for Børn og Unge” (Drotner, 2013). 
Also evident in this group of Nordic countries is the close connection of media education policies with civic society, $N G O$ and the media sector. For instance, Finnish media education policy has explicit links with several NGO organizations; some of these encourage media education in together with the public governments like the Finnish Society on Media Education, Media Education Centre Metka and Koulukino - School Cinema Association, which are funded by the Ministry of Education and Culture. Other NGO include the Mannerheim League for Child Welfare, Kerhokeskus - the Centre for School Clubs, Save the Children Finland and the Finnish Parents' League. Promoting media literacy has become common also in within media sector companies. For example, the Finnish Newspaper Association organizes newspaper education and the Finnish Broadcasting Company has funded many kinds of media education projects.

\section{The challenges of establishing legal frameworks on a European level}

Across Europe, media and information literacy is characterised by lack of harmonization, fragmentation, inconsistent levels of implementation and a problem of marginalisation arising from the fact that education remains in nearly all cases a subsidiary issue. As we describe, there is little evidence of coordination across formal and semi-formal sectors and in terms of systematic integration of research-based insights, assessments and results.

The lack of a single legal definition of media education in many EU countries, particularly newer member states, as a prerequisite to the development of media literacy implementation remains an important barrier. In those countries in which a legal definition is indicated, problems remain in fully implementing it in school curricula, as cited for example in Austria or Spain. While at the national level, a positive view of MIL may be projected. However, the vague nature of its formulation and the lack of guidelines have led to inconsistent and patchy integration of media education into classroom settings. In countries such as Spain, where there is a legal emphasis on media literacy and where education policies do take into account media and new technology in the classroom, its implementation has in most cases, been based on mere instrumental training in technological applications, without any critical attention to the object of study. 
Progress in adopting a policy framework and implementing the project of media education in many European countries has been relatively slow. This arises primarily in the delayed transposition of the AVMSD into national law. While many European researcher and commentators have called for a special EU directive to include media literacy in their national education legislation and in the curriculum, education remains the primary responsibility of individual member states and not the European Union.

What is clear is that to enhance media education in Europe a more defined legal basis for media and information literacy is needed. Currently, there is a strong disconnect between those legal definitions that do exist and the respective domains in which media and information literacy is implemented. Such a legal definition should prescribe how MIL has to be integrated more in daily school life with support for teachers in the development of their own media literacy and media education competencies. This also requires a better integration of media education in teacher training curricula as well as more possibilities for in-service teacher training. Therefore the focus needs to be not only on computer literacy but also on digital literacy and media literacy in general. In all countries, the school curricula needs to integrate a media education course in which students are required to develop all dimensions of digital competition.

While it is evident from the review of the legal and policy positioning of media literacy in the countries participating in the Translit project that the subject continues to attract policymakers' attention and to be referenced in varying degrees of detail as a public policy priority, to be effective, there needs greater integration between principles and their implementation, and between regulatory frameworks and evaluation and funding. Further development of MIL at the level of legal and policy frameworks should provide clearer guidance - supported by research and evidence - to the anticipated outcomes and means of implementation. This requires, for instance, much closer connection between educational activities in both formal and non-formal settings and the agencies involved in the media regulatory space. In this context, media policy regarding overall governance and regulation of the sector has a key role to play and can ensure through effective evaluation the attainment of outcomes that are seen as vital to a healthy, information-based, public sphere.

\section{References}


Banerjee, I., Seneviratne, K. (2005). Public Service Broadcasting: A best practices sourcebook. UNESCO. Retrieved from http://unesdoc.unesco.org/images/0014/001415/141584e.pdf

Brikše, I., Freibergs, V., Spurava, G. (2013): Media and Information Literacy in Latvia. Latvia Translit Report. Retrieved from: http://ppemi.enscachan.fr/data/media/colloque140528/rapports/LATVIA_2014.pdf

Council of Europe. (2006a). Public service media in the information society. Media Division, Directorate General of Human Rights.

Council of Europe. (2006b). Recommendation Rec(2006)12 of the Committee of Ministers to member states on empowering children in the new information and communications environment. Retrieved from

https://wcd.coe.int/ViewDoc.jsp?p=\&Ref=Rec(2006)12\&Sector=secCM\&Language=lanEnglish\& Ver $=$ original\&BackColorInternet $=9999 \mathrm{CC} \&$ BackColorIntranet $=$ FFBB55\&BackColorLogged $=\mathrm{FF}$ $\underline{\text { AC75\&direct }=\text { true }}$

Council of Europe. (2006c). The Internet literacy handbook. Media Division, Directorate General of Human Rights. Retrieved January 24, 2016, from http://book.coe.int/eur/en/new-informationtechnologies/3443-the-internet-literacy-handbook.html

Council of the European Union. Recommendation of the European Parliament and of the Council of 18 December 2006 on Key Competences for Lifelong Learning (2006/962/EC). Retrieved from http://eur-lex.europa.eu/legal-content/EN/TXT/PDF/?uri=CELEX:32006H0962\&from=EN

Drotner, K. (2013). Media and Information Literacy Policies in Denmark. Denmark Translit Report. Retrieved from: http://ppemi.enscachan.fr/data/media/colloque140528/rapports/DENMARK_2014.pdf

European Commission. (2003). The Future of European Regulatory Audiovisual Policy. Brussels. Retrieved from http://eurlex.europa.eu/LexUriServ/LexUriServ.do?uri=COM:2003:0784:FIN:EN:PDF

European Commission. (2007). A European approach to media literacy in the digital environment $[\operatorname{COM}(2007)$ 833. Communication from the Commission to the European Parliament, the Council, the European Economic and Social Committee and the Committee of the Regions of 20 December 2007. Brussels, European Commission.

European Union. (2010). Directive 2010/13/EU of the European Parliament and of the Council of 10 March 2010 on the coordination of certain provisions laid down by law, regulation or administrative action in Member States concerning the provision of audiovisual media services (Audiovisual Media Services Directive). Retrieved from http://eurlex.europa.eu/LexUriServ/LexUriServ.do?uri=CELEX:32010L0013:EN:NOT

Frau-Meigs, D. (2008). Media Literacy and Human Rights: Education for Sustainable Societies. Medij. Istraž., 14, 51-82.

Frau-Meigs, D. (2011). Media matters in the cultural contradictions of the 'information society': towards a human-rights-based governance. Strasbourg, France: Council of Europe Publishing. 
Frau-Meigs, D., Loicq, M., Boutin, P. (2013): Media and Information Literacy Policies in France. France Translit Report. Retrived from: http://ppemi.ens-

cachan.fr/data/media/colloque140528/rapports/FRANCE_2014.pdf

Grandío, M., Vicente, M., García-Matilla, A., Gutiérrez-Martín, A., Marta-Lazo, C. (2013): Media and Information Literacy Policies in Spain. Spain Translit Report. Retrived from:

http://ppemi.ens-cachan.fr/data/media/colloque140528/rapports/SPAIN_2014.pdf

Kammerl, R., Hasebrink, U. (2013): Media and Information Literacy in Germany. Germany

Translit Report, 2014. Retrived from: http://ppemi.ens-

cachan.fr/data/media/colloque140528/rapports/GERMANY_2014.pdf

Kotilainen, S., Kupiainen, R. (2013): Media and Information Literacy Policies in Finland. (Finland Translit Report, 2014. Retrieved from: http://ppemi.ens-

cachan.fr/data/media/colloque140528/rapports/FINLAND_2014.pdf

Krucsay, S. 2006. Interplay human rights - media literacy - empowerment -- an area of conflict or an area of hope? Presented at the Pan-European Forum on "Human Rights in the Information Society: Empowering children and young people," Council of Europe. Retrieved from http://www.coe.int/t/e/human_rights/media/links/events/Forum2006YerevanSpeechSK_en.asp\#To pOfPage

Masterman, L. (1985). Teaching the Media. London: Comedia.

Matović, M., Milin, S., Perković, (2013): Media and Information Literacy Policies in Serbia. Serbia Translit Report. Retrived from: http://ppemi.enscachan.fr/data/media/colloque140528/rapports/SERBIA_2014.pdf

McDougall, J., Livingstone, S., Sefton-Green, S., Fraser, P. (2013): Media and Information Literacy Policies in United Kingdom. United Kingdom Translit Report, 2013. Retrieved from: http://ppemi.ens-cachan.fr/data/media/colloque140528/rapports/UNITED-KINGDOM_2014.pdf

Ministry of Education and Culture. (2013). Good Media Literacy. National Policy Guidelines 2013-2016. Helsinki, Finland: Department for Cultural, Sport and Youth Policy. Retrieved from http://www.minedu.fi/export/sites/default/OPM/Julkaisut/2013/liitteet/OKM13.pdf?lang=en

O’Neill, B. (2013): Media and Information Literacy Policies in Ireland. Ireland Translit Report. Retrieved from: http://ppemi.enscachan.fr/data/media/colloque140528/rapports/IRELAND_2014.pdf

Stanila, C., Fotiade, N. (2013): Media and Information Literacy Policies in Romania. (Romania Translit Report, 2013). Retrieved from: http://ppemi.enscachan.fr/data/media/colloque140528/rapports/ROMANIA_2014.pdf

Turcilo, L. Tajić, L. (2013). Media and Information Literacy Policies in Bosnia-Herzegovina. Bosnia-Herzegovina Translit Report. Retrieved from: http://ppemi.enscachan.fr/data/media/colloque140528/rapports/BOSNIA-HERZEGOVINA_2014.pdf 
Universitat Autònoma de Barcelona. (2007). Study on the current trends and approaches to media literacy in Europe. Brussels: Commission of the European Communities. Retrieved from http://ec.europa.eu/avpolicy/media_literacy/studies/index_en.htm

Zgrabljic-Rotar, N. (2006). Media Literacy and Civil Society. Sarajevo: Mediacentar. 